\title{
SISTEM INFORMASI PENYUSUNAN ANGGARAN PROPOSAL PENELITIAN DOSEN
}

\author{
'Syahrul Anuar, ${ }^{2}$ llyas \\ 1,2 Program Studi Sistem Informasi, Fakultas Teknik dan Ilmu Komputer \\ Universitas Islam Indragiri (UNISI) \\ Jl. Provinsi No. 01 Tembilahan Hulu, Indragiri Hilir, Riau - Indonesia \\ Email:syahrulanuar20@gmail.com,daengilyas01@gmail.com
}

\begin{abstract}
ABSTRAK
Seiring berkembangnya zaman, pembuatan pengajuan proposal penelitian dosen semakin berkembang setiap tahunnya, terutama tahapan-tahapan pengajuan proposal penelitian dosen yang semakin sulit dimana selalu membuat para dosen kewalahan dan kesulitan dalam mengerjakannya terlebih pada tahapan penyusunan anggaran, dipembuatan proposal penelitian dosen perlu segera dilakukan perubahan mendasar yakni perbaikan proses penyusunan anggaran pengajuan proposal penelitian dosen. Hal ini dimaksudkan agar kesalahan yang terjadi seawal mungkin dapat diatasi, sehingga lebih mudah melakukan tindakan perbaikan dan penyesuaian. Mencermati hal itu, dapatlah dikatakan bahwa dalam penyusunan anggaran penelitian dosen harus dilakukan dengan baik. Agar penyusunan anggaran efektif dan efesien perlu adanya dobrakan sistem informasi yang menangani penyusunan anggaran pengajuan proposal penelitian dosen. Dengan dibangunnya sistem ini diharapkan dapat memberikan informasi yang tepat pada dosen dalam penyusunan anggaran proposal penelitian lebih efektif dan akurat.
\end{abstract}

Kata kunci: proposal penelitian dosen, SDLC, UML.

\section{PENDAHULUAN}

Pada masa ini, banyak hal-hal yang dapat dijadikan sebagai sarana informasi. Kita dapat mencari berita/informasi sebanyak - banyaknya dari sarana teknologi yang telah dapat dijadikan sebagai sarana informasi. Teknologi masa kini yang dapat dijadikan sebagai sarana informasi dan berita adalah internet. Internet dapat memberikan informasi yang kita butuhkan, tetapi internet juga dapat memberikan informasi berdampak negative. Komputer memberikan satu solusi yang tepat dalam menghasilkan informasi yang terkini. Oleh karena itu, dibutuhkan tenaga-tenaga ahli di bidang komputer, guna memenuhi kebutuhan informasi.

Salah satu teknologi informasi tersebut adalah internet yang digunakan sebagai media informasi dan komunikasi. Melalui internet setiap orang dapat mengakses informasi berharga dari jutaan situs yang ada tanpa harus keluar rumah untuk mencari informasi yang dibutuhkan, selain pusat informasi internet juga identik dengan Website, karena Website sangat populer belakangan ini. Website lebih banyak dikenal dikhalayak umum terutama untuk penyampaian informasi dan komunikasi kepada pengguna. Melaui internet dengan menggunakan media website banyak membantu dalam memenuhi kebutuhan informasi. Teknologi internet sangat sesuai untuk memenuhi tuntutan kecepatan pelayanan yang diinginkan, mengingat internet dapat diakses kapan saja, dimana saja serta implementasinya relatif murah.

Pengajuan proposal penelitian dosen pada sistem informasi penelitian dan pengabdian kepada masyarakat terus melakukan perbaikan, terutama pada tahapan pengajuan proposal penelitian dosen yang semakin sulit, dimana selalu membuat para dosen kesulitan dalam mengerjakannya terlebih pada tahapan penyusunan anggaran, dipembuatan proposal penelitian dosen perlu segera dilakukan perubahan mendasar pada perbaikan proses penyusunan anggaran pengajuan proposal penelitian dosen. Hal ini dimaksudkan agar kesalahan yang terjadi seawal mungkin dapat diatasi, sehingga lebih mudah melakukan tindakan perbaikan dan penyesuaian. Mencermati hal itu, dapatlah dikatakan bahwa dalam penyusunan anggaran penelitian dosen harus dilakukan dengan baik. Agar penyusunan anggaran efektif dan efesien perlu adanya dobrakan sistem informasi yang menangani penyusunan anggaran pengajuan proposal penelitian dosen. 
Berdasarkan penjabaran latar belakang diatas, dapat di rumuskan masalah sebagai berikut: (1) Membuat suatu sistem penyusunan anggaran yang valid, efektif dan akurat untuk penyusunan anggaran proposal penelitian dosen. (2) Terbatasnya waktu dalam pengajuan proposal penelitian dosen diakibatkannya tidak valid penyesuian penyusunan anggaran proposal penelitian dosen, yang membuat keterlambatan bahkan ditolaknya pengajuan proposal penelitian dosen. (3) Belum adanya sistem yang menerapkan pemberitahuan titik kesalahan secara otomatis pada pembuatan proposal anggaran penelitian dosen.

Tujuan yang ingin di capai adalah sebagai berikut: (1) Merancang Sistem Informasi penyusunan anggaran proposal penelitian dosen yang berbasis website. (2) Untuk membantu seorang dosen dalam melakukan identifikasi kesalahan penyusunan anggaran pada proposal dosen. (3) Untuk memberikan informasi secara mudah dan cepat tentang kesalahan tidak validnya pengkalkulasian dalam penyusunan anggaran proposal dosen. (4) Untuk membangun sistem informasi penyusunan anggaran proposal dosen menggunakan software PHP sehingga tidak membutuhkan banyak waktu dan biaya bagi penggunanya.

Manfaat dari penelitian ini adalah sebagai berikut: (1) Sebagai sarana untuk mengetahui dan memahami jenis kesalahan pemyusunan anggaran berdasarkan form informasi yang timbul pada layar dalam rangka membantu kerja seorang dosen. (2) Dengan adanya sistem informasi penyusunan anggaran proposal dosen memperkecil kesalahan-kesalahan pengkalkulasian sehingga mempermudah dan mempercepat kerja seorang dosen dalam pembuatan pengajuan anggaran.

\section{TINJAUAN PUSTAKA}

\subsection{Sistem}

Sistem adalah kumpulan atau himpunan dari unsur atau variabel-variabel yang saling terkait, saling berinteraksi, dan saling tergantung satu sama lain untuk mencapai tujuan (Tohari, 2013). Selain itu sistem juga dapat didefinisikan sebagai sekumpulan objek-objek yang saling berelasi dan berinteraksi serta hubungan antar objek bisa dilihat sebagai satu kesatuan yang dirancang untuk mencapai satu tujuan yang telah ditetapkan [1]. Sistem menurut Winarno (2006) adalah sebagai berikut : "Sekumpulan komponen yang saling bekerja sama untuk mencapai tujuan tertentu [2]. Sedangkan menurut Kristanto (2007) sistem juga merupakan kumpulan elemen-elemen yang saling terkait dan bekerja sama untuk memroses masukan (input) yang ditujukan kepada sistem tersebut dan mengolah masukan tersebut sampai menghasilkan keluaran (output) yang diinginkan [3].

\subsection{Informasi}

Informasi adalah data yang telah dikelola dan diproses untuk memberika arti dan memperbaiki proses pengambilan keputusan, Menurut McLeod Informasi adalah data yang diolah menjadi bentuk lebih berguna dan lebih berarti bagi yang menerimanya. Informasi merupakan data yang telah diproses sedemikian rupa sehingga meningkatkan pengetahuan seseorang yang menggunakan. Sistem apapun tanpa informasi tidak akan berguna, karena sistem tersebut akan mengalami kemacetan dan akhirnya berhenti (Ivan Arifard Watung, dkk, 2014) [4]. Menurut B.davis (1985) mendefenisikan informasi sebagai data yang telah diolah menjadi bentuk yang lebih berarti dan berguna bagi penerimanya untuk mengambil keputusan masa kini maupun yang akan datang [5].

\subsection{Sistem Informasi}

Ada beberapa definisi sistem informasi, berdasarkan beberapa defenisi tersebut, dapat disimpulkan bahwa sistem informasi mencakup sejumlah komponen (manusia, komputer, teknologi informasi dan prosedur kerja), ada sesuatu yang diproses (data menjadi informasi), dan dimaksudkan untuk mencapai suatu sasaran atau tujuan. Sistem informasi adalah kombinasi antar prosedur kerja, informasi, orang, dan teknologi informasi yang diorganisasikan untuk mencapai tujuan dalam sebuah organisasi (Alter,1992), Sistem informasi adalah kumpulan perangkat keras dan perangkat lunak yang dirancang untuk mentransformasikan data kedalam bentuk informasi 
yang berguna (Bodnar dkk,1993), Sistem informasi adalah suatu sistem buatan manusia yang secara umum terdiri dari sekumpulan komponen berbasis komputer dan manual yang dibuat untuk menghimpun, menyimpan, dan mengelola data serta menyediakan informasi keluaran kepada para pemakai (Gelins dkk,1990). Sistem informasi adalah sebuah rangkaian prosedur formal dimana data dikelompokan, diproses menjadi informasi, dan didistribusikan kepada pemakai (Hall,2001), Sistem informasi mengumpulkan, memproses, menyimpan, menganalisa, dan menyebarkan informasi untuk tujuan yang spesifik (Turban dkk, 1999), Sistem informasi adalah kerangka kerja yang mengoordinasikan sumber daya (manusia, komputer) untuk mengubah masukan (input) menjadi keluaran (informasi), guna mencapai sasaran - sasaran perusahaan (Wilkinson,1992) [4]. Sedangkan Tantra berpendapat sistem informasi adalah kumpulan dari berbagai prosedur di dalam perusahaan untukmenghasilkan informasi yang dibutuhkan. Sistem informasi mengolah data menjadi informasi yang bernilai untuk mendukung manajemen mengambil keputusan. Karena peran strategisnya ini sistem informasi berperan penting dalam tmbuh kembang organisasi dan perusahaan [6]. Sedangkan menurut Ladjamudin (2005) Sistem informasi adalah suatu sistem didalam organisasi yang mempertemukan kebutuhan pengolahan transaksi, mendukung operasi, bersifat manajerial, dan kegiatan strategi dari suatu organisasidan menyediakan pihak luar tertentu dengan laporanlaporan yang diperlukan. Sedangkan menurut Indrajit (2000) sistem informasi dapat dianalogikan sebagai sebuah permintaan (demand) dari masyarakat industri, ketika kebutuhan akan saran pengolahan data komunikasi yang cepat dan murah (menembus ruang dan waktu) [5]. Sedangkan menurut Stair and Reynolds (2010) seperti disebutkan sebelumnya, sistem informasi adalah seperangkat elemen atau komponen yang saling terkait yang mengumpulkan (input), memanipulasi (process), menyimpan dan menyebarkan (output) data dan informasi, dan memberikan reaksi korektif (mekanisme umpan balik) untuk memenuhi tujuan, mekanisme umpan balik adalah komponen yang membantu organisasi mencapai tujuan mereka, seperti meningkatkan laba atau meningkatkan layanan pelanggan [7]

\subsection{Karakteristik Sistem}

Menurut (Tohari, 2013), suatu sistem mempunyai karakteristik atau sifat tertentu, yaitu : (1) Komponen atau elemen (Components), suatu sistem terdiri dari komponen-komponen yang berinteraksi, yang artinya saling bekerja sama membentuk satu kesatuan. (2) Batas Sistem (Boundary), batas sistem merupakan daerah yang membatasi antara sistem yang satu dengan sistem yang lainnya atau dengan lingkungan luarnya. Adanya batas sistem, maka sistem dapat membentuk suatu kesatuan, karena dengan batas sistem ini, fungsi dan tugas dari subsistem satu dengan yang lainnya berbeda tetapi tetap saling berinteraksi. Dengan kata lain, batas sistem merupakan ruang lingkup atau scope dari sistem atau subsistem itu sendiri. (3) Lingkungan Luar Sistem (Environment), lingkungan luar sistem adalah segala sesuatu diluar batas sistem yang mempengaruhi operasi suatu sistem. Lingkungan luar sistem dapat bersifat menguntungkan atau merugikan. Lingkungan luar sistem yang bersifat menguntungkan harus dipelihara dan dijaga supaya tidak hilang pengaruhnya. Sedangkan, lingkungan yang bersifat merugikan harus dihilangkan supaya tidak menggangu operasi dari sistem. (4) Penghubung Sistem (Interface), penghubung sistem merupakan suatu media (penghubung) antara satu subsistem dengan subsistem lainnya yang membentuk satu kesatuan, sehingga sumber-sumber daya mengalir dari subsistem yang satu ke subsistem lainnya. Dengan kata lain, melalui penghubung, output dari subsistem akan menjadi input bagi subsistem lainnya. (5) Masukan (Input), input adalah energi atau sesuatu yag dimasukkan ke dalam suatu sistem yang dapat berupa masukkan yaitu energi yang dimasukkan supaya sistem dapat beroperasi atau masukkan sinyal yang merupakan energi yang diproses untuk menghasilkan suatu luaran. (6) Luaran (Output), merupakan hasil dari energi yang diolah dan diklasifikasikan menjadi luaran yang berguna, juga merupakan luaran atau tujuan akhir dari sisem. (7) Pengolah (Proses), suatu sistem mempunyai bagian pengolah yang akan mengubah input menjadi output. (8) Sasaran (Objektive), sasaran dari sistem sangat menentukan sekali 
masukan yang dibutuhkan sistem dan keluaran yang akan dihasilkan sistem. Suatu sistem dikatakan berhasil bila mengenai sasaran atau tujuannya [1].

\subsection{Model Pengembangan Sistem}

Dalam pengembangan sistem informasi, salah satu model dinamakan siklus hidup pengembangan sistem (Systems Development Life Cycle/SDLC) yang memuat langkah-langkah yang semestinya diikuti dalam perancangan basis data dan pemrogram, untuk menspesifikasikan, mengembangkan, serta memelihara sistem informasi. Proses ini sering digambarkan secara bertingkat seperti yang diperlihatkan pada Gambar 1. Metafora bertingkat atau air terjun (waterfall) digunakan untuk menggambarkan bahwa keluaran dari suatu tahap merupakan masukan untuk tahap berikutnya. Walaupun demikian, seperti yang diperlihatkan di Gambar 1 proses ini tidak benar-benar berjalan secara linear, suatu tahap mungkin berjalan secara parallel serta dimungkinka untuk kembali pada langkah berikutnya (proses iterasi) saat suatu keputusan tertentu perlu dipertimbangkan lagi (Nugroho, 2014) [8].

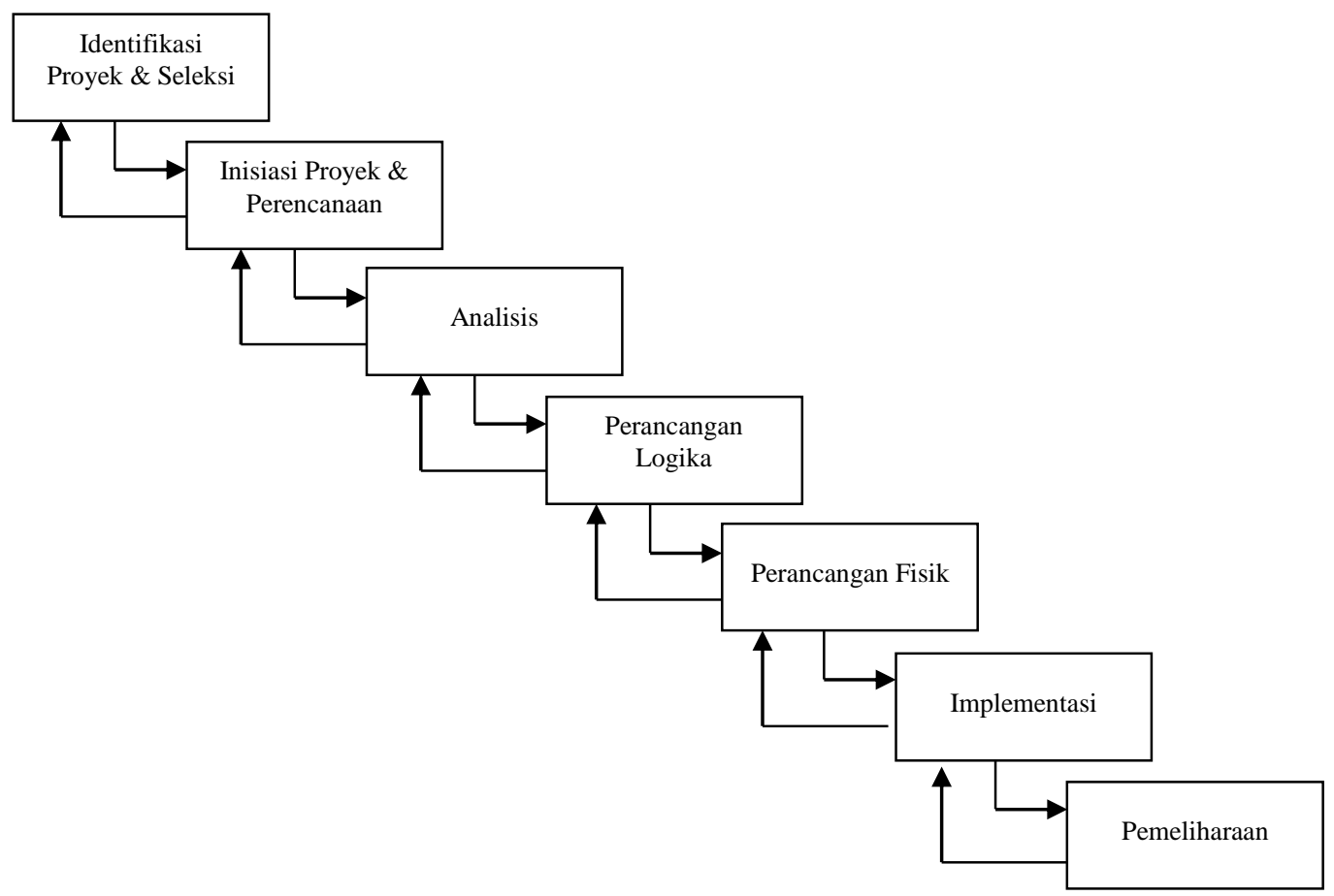

Gambar 1 Pengembangan Sistem SDLC

\subsection{Sistem Informasi Penelitian dan Pengabdian kepada Masyarakat}

Sistem Informasi Penelitian dan Pengabdian kepada Masyarakat yang selanjutnya disebut Simlitabmas. Dengan Simlitabmas, proses pengajuan dan seleksi proposal, monitoring dan evaluasi pelaksanaan, laporan akhir, penggunaan anggaran, serta pelaporan hasil-hasil penelitian dan pengabdian kepada masyarakat dapat dikelola dengan baik sehingga transparansi, efisiensi dan akuntabilitas dapat dijamin.

Perguruan tinggi berkewajiban menyelenggarakan penelitian dan pengabdian kepada masyarakat disamping melaksanakan pendidikan sebagaimana diamanahkan oleh Undangundang Nomor 20 Tahun 2003 tentang Sistem Pendidikan Nasional Pasal 20. Sejalan dengan kewajiban tersebut, Undang-undang Nomor 12 Tahun 2012 tentang Pendidikan Tinggi Pasal 45 menegaskan bahwa penelitian di perguruan tinggi diarahkan untuk mengembangkan ilmu pengetahuan dan teknologi, serta meningkatkan kesejahteraan masyarakat dan daya saing bangsa. Dalam pasal tersebut juga ditegaskan bahwa pengabdian kepada masyarakat merupakan kegiatan sivitas akademika dalam mengamalkan dan membudayakan ilmu 
pengetahuan dan teknologi untuk memajukan kesejahteraan umum dan mencerdaskan kehidupan bangsa.

Selanjutnya dalam Pasal 1 Peraturan Menteri Riset, Teknologi, dan Pendidikan Tinggi Republik Indonesia Nomor 44 tahun 2015 tentang Standar Nasional Pendidikan Tinggi juga telah menyebutkan bahwa Standar Nasional Pendidikan Tinggi, adalah satuan standar yang meliputi Standar Nasional Pendidikan, ditambah dengan Standar Nasional Penelitian, dan Standar Nasional Pengabdian kepada Masyarakat. Dalam pasal tersebut juga dijelaskan bahwa Standar Nasional Penelitian dan Pengabdian kepada Masyarakat adalah kriteria minimal tentang sistem penelitian dan Pengabdian kepada Masyarakat pada perguruan tinggi yang berlaku di seluruh wilayah hukum Negara Kesatuan Republik Indonesia.

\subsection{Perancangan UML (Unifield Modeling Language)}

UML (unified modeling language) adalah Bahasa pemodelan untuk sistem atau perangkat lunak yang berparadigma "berorientasi objek" (Priana dan Fitriani, 2016) [9].

\subsection{Web}

Web adalah suatu layanan informasi di internet yang berbasis grafis dan memungkinkan siapapun untuk berada 24 jam/sehari di internet. Jenis-jenis web menurut kamus istilah internet penerbit Wahana Komputer Semarang adalah sebagai berikut: (1) Web Browser, web browser adalah suatu program dimana kita dapat mengambil dokumen-dokumen HTML dari web server dengan menggunakan protokol dan format HTTP yang satu ke yang lainnya di web server yang sama atau di server lain, misalnya : Internet Explorer, Opera. (2) Web Edit, web edit adalah editor teks HTML berbasis Windows, seperti : Ms. Front Page, NotePad. (3) Web Page, web page adalah kemasan yang berisi suara, grafis, film dan teks yang berasal dari file-file data HTML. (4)Web Server, web server adalah sistem komputer di suatu organisasi yang berfungsi sebagai server untuk fasilitas WWW, dan dapat diakses oleh seluruh pemakai internet, seperti PWS, IIS, dan Apache. (5) Website, website adalah lokasi-lokasi yang berada di internet. Website juga merupakan tempat atau alamat di internet yang merupakan sampul halaman yang berisi sebuah situs web (Hasibuan, 2010) [10].

\subsection{PHP}

PHP merupakan bahasa berbentuk script yang ditempatkan dalam server dan diproses di server, dan hasilnya dikirimkan ke client, tempat pemakai menggunakan browser. PHP pertama kali dibuat oleh Rasmus Lerdorf pada tahun 1995. Pada waktu itu PHP bernama FI (Form Interpreted). Pada saat tersebut PHP adalah sekumpulan script yang digunakan untuk mengolah data form dari web. Perkembangan selanjutnya adalah Rasmus melepaskan kode sumber tersebut dan menamakannya PHP/FI, pada saat itu kepanjangan dari PHP/FI adalah Personal Home Page/Form Interpreter (Adiyanto dkk, 2013) [11].

\subsection{Black Box and White Box}

Black Box Testing berfokus pada spesifikasi fungsional dari perangkat lunak. Tester dapat mendefinisikan kumpulan kondisi input dan melakukan pengetesan pada spesifikasi fungsional program. Black Box Testing bukanlah solusi alternatif dari White Box Testing tapi lebih merupakan pelengkap untuk menguji hal-hal yang tidak dicakup oleh White Box Testing (Mustaqbal, 2015) [14].

White Box Testing adalah salah satu cara untuk menguji suatu aplikasi atau software dengan cara melihat modul untuk dapat meneliti dan menganalisa kode dari program yang di buat ada yang salah atau tidak. Kalau modul yang telah dan sudah di hasilkan berupa output yang tidak sesuai dengan yang di harapkan maka akan dikompilasi ulang dan di cek kembali kode-kode tersebut hingga sesuai dengan yang diharapkan (Nidhra and Dondetti, 2012) [15]. Kelemahan White Box Testing adalah pada perangkat lunak yang jenisnya besar, metode white box testing ini dianggap boros karena melibatkan banyak sumberdaya untuk melakukannya. 


\section{METODE PENELITIAN}

Dalam menganalisa suatu sistem diperlukan data-data, untuk mengambil data maka dilakukan teknik pengumpulan data untuk keperluan penelitian sebagai berikut :

1. Observasi ( observation )

Teknik pengumpulan data dengan melakukan pengamatan dan penelitian secara langsung apakah sistem yang diteliti ada atau tidak di prodi sistem informasi tersebut

2. Wawancara (Interview )

Teknik pengumpulan data yang dilakukan melalui tatap muka dan mengadakan tanya jawab secara langsung antara peneliti dengan prodi sistem informasi di universitas islam indragiri.

3. Studi literatur

Teknik yang menggunakan buku - buku atau artikel - artikel lain yang dapat membantu permasalahan untuk menyelesaikan masalah yang dapat dipakai sebagai landasan teori.

\section{HASIL DAN PEMBAHASAN}

Analisa sistem dilakukan setelah tahapan identifikasi dan perencanaan sistem. Tahapan analisa sistem merupakan tahapan yang kritis dan sangat penting karena kesalahan ditahap ini akan menyebabkan kesalahan di tahap selanjutnya.

Use Case Diagram

Untuk mengetahui logika apa yang dikerjakan oleh pengguna sistem. Maka dirancanglah sebuah diagram use case. Dengan diagram ini juga dapat diketahui fungsi yang digunakan oleh sistem yang sekarang. Use case diagram dapat dilihat pada Gambar 2 dibawah ini.

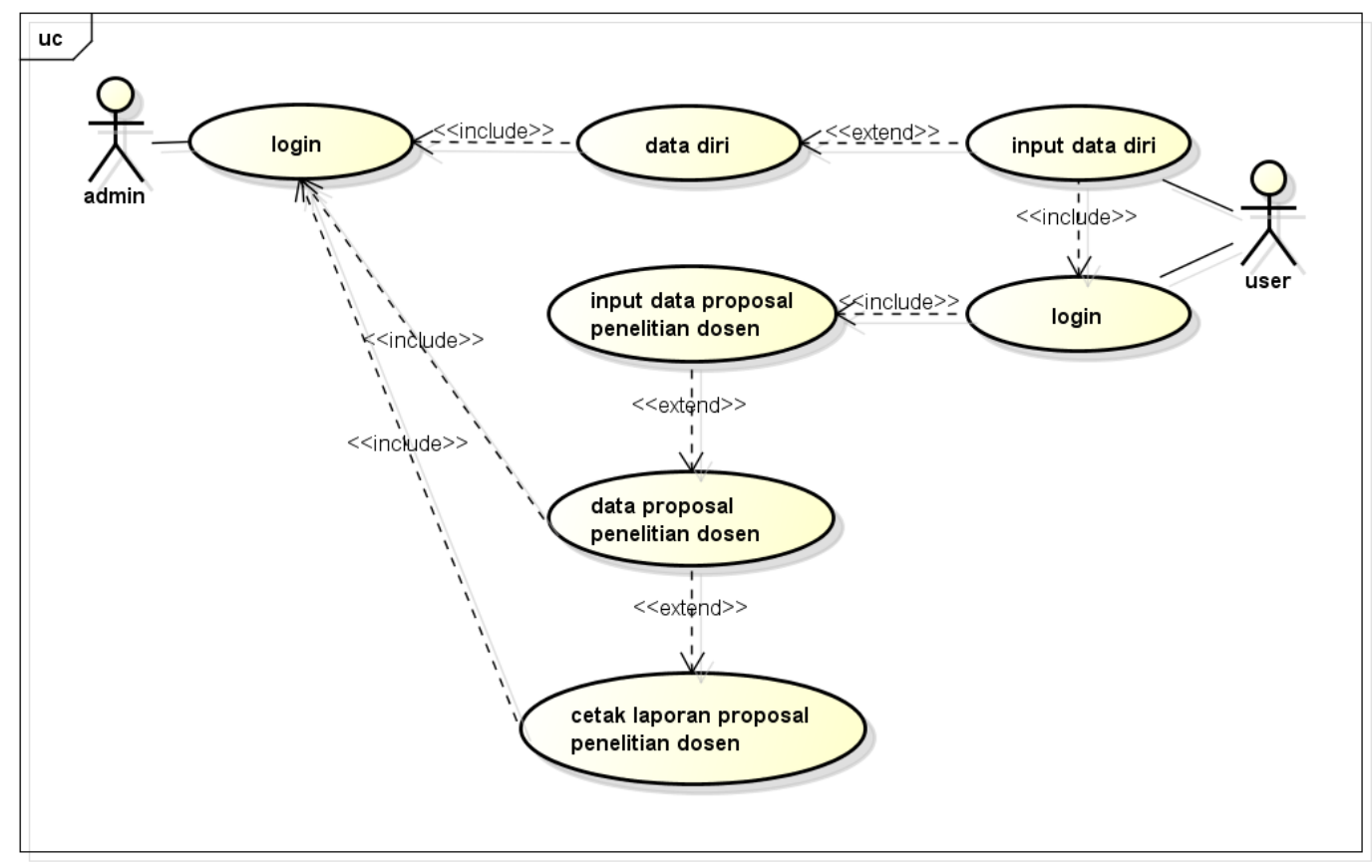

Gambar 2 Use Case Diagram

Skenario use case digunakan untuk memudahkan dalam menganalisa fase-fase yang akan dikerjakan selanjutnya. Adapun tahapan yang dapat dilakukan dalam sistem informasi proposal penelitian dosen tersebut adalah untuk aktor admin setelah melakukan login, admin dapat mengecek data proposal penelitian dosen dan mencetaknya. Untuk aktor user setelah melakukan login, user dapat melakukan penginputan data proposal penelitian dosen. Dan admin juga dapat melihat data user.

Sequence Diagram

Sequence diagram pengajuan proposal (user) untuk sistem informasi proposal penelitian dosen dapat dilihat pada Gambar 3 di bawah ini. 


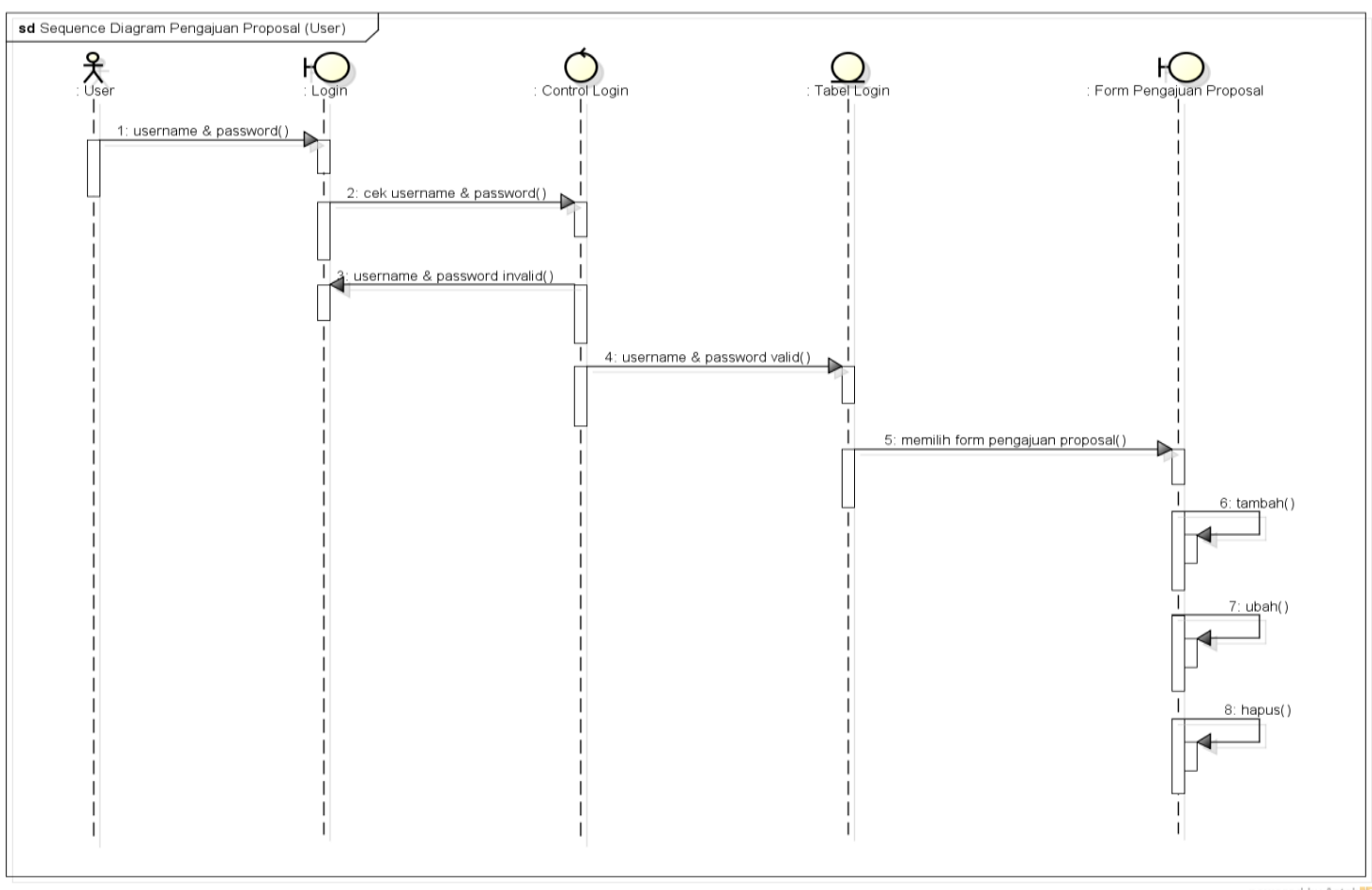

Gambar 3 Sequence Diagram Pengajuan Proposal (User)

Setelah user login dengan username dan password yang benar, user bisa memilih form pengajuan proposal jika ingin melakukan pengajuan proposal penelitian dosen pada sistem tersebut. Di dalam form pengajuan proposal, user dapat melakukan aksi seperti tambah, ubah, dan hapus.

\section{Activity Diagram}

Activity diagram pengajuan proposal (user) untuk sistem informasi proposal penelitian dosen dapat dilihat pada Gambar 4 di bawah ini.



Gambar 4 Activity Diagram Pengajuan Proposal (User)

Anuar, Sistem Informasi Penyusunan Anggaran Proposal Penelitian Dosen 
Dari gambar di atas, dapat dijelaskan bahwa saat user ingin melakukan pengajuan proposal, user harus memilih form pengajuan proposal. Kemudian user dapat menginputkan data proposal. Setelah data terisi, simpan data ke dalam sistem.

Class Diagram

Class diagram membantu kita dalam visualisasi struktur kelas-kelas dari suatu sistem dan merupakan tipe diagram yang paling banyak di pakai. Class diagram memperlihatkan hubungan antara kelas dan penjelasan detail tiap-tiap kelas di dalam model desain dari suatu sistem, seperti Gambar 5 berikut ini.



\section{Gambar 5 Class Diagram}

powered by Astaher

Dari tabel di atas dapat dijelaskan bahwa dalam pembuatan aplikasi proposal penelitian dosen memiliki bebrapa database sebagai tempat penyimpanan datanya, yaitu tabel admin, tabel user, tabel proposal, dan tabel rab.

\subsection{Implementasi}

Implementasi merupakan tahapan penerapan dan pengoperasian sistem pada keadaan yang sebenarnya, sehingga akan diketahui apakah sistem yang telah dibangun benar-benar dapat berjalan dan sesuai dengan tujuan yang ingin dicapai. Setelah analisa dan perancangan sistem 
selesai, maka langkah selanjutnya yang akan dilakukan adalah implementasi atau penerapan sistem.

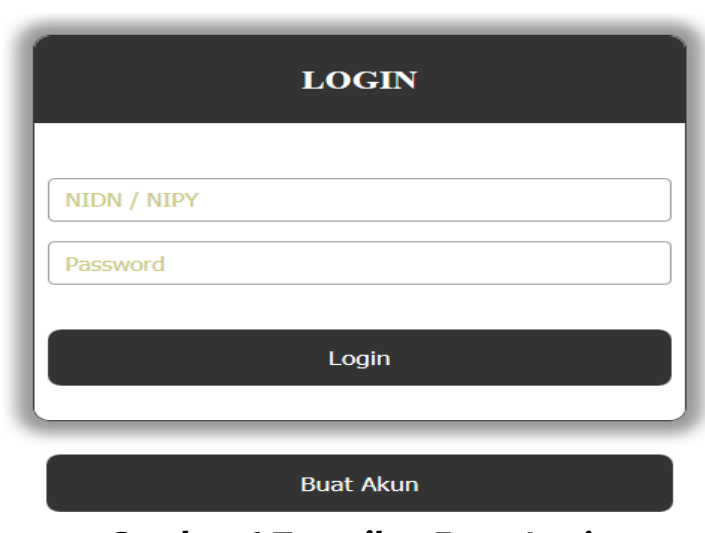

\section{Gambar 6 Tampilan Form Login}

Gambar 6 di atas merupakan tampilan form Login. Pada halaman login, user yang telah mendaftarkan diri cukup memasukkan NIDN/NIPY dan password yang telah di daftarkan sebelumnya setelah itu cukup menekan tombol Login, dan selanjutnya sistem akan membawa user ke tampilan halaman awal sisem. Apabila user belum memiliki akun, maka user bisa membuat akun diri terlebih dahulu.



Gambar 7 di atas merupakan tampilan form daftar, pada saat user meng-klik link buat akun yang berada pada halaman login, maka sistem akan membawa user pada form daftar. Disini user harus memasukkan NIPY/NIDN, Nama, Jenis Kelamin, Alamat, Nomor Handphone, dan Password. Setelah itu user cukup meng-klik tombol Daftar dan data user akan disimpan ke dalam database. User bisa login menggunakan NIPY/NIDN dan password yang telah di daftarkan tadi. 


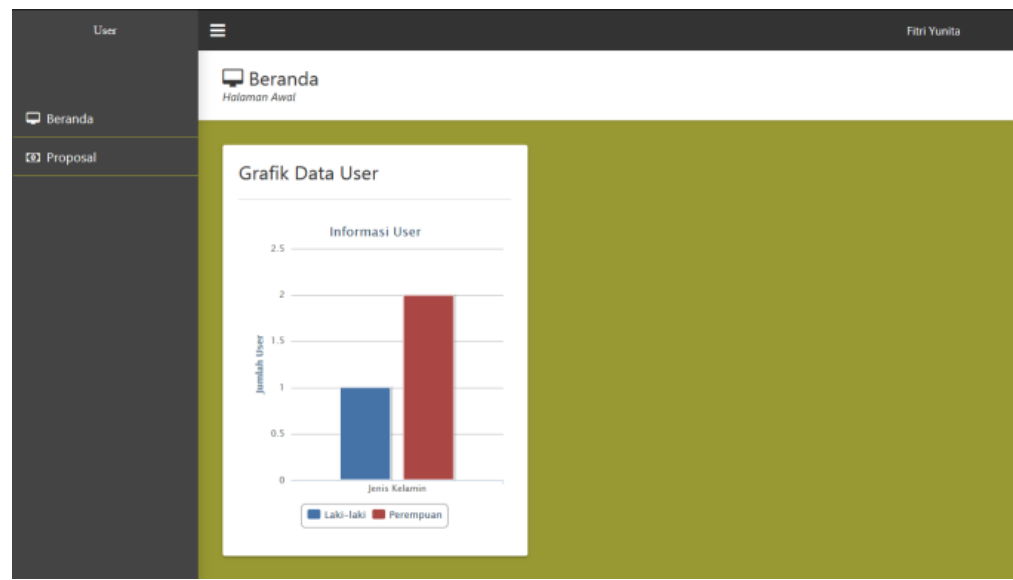

\section{Gambar 8 Tampilan Awal Sistem}

Gambar 8 di atas merupakan tampilan halaman utama user, setelah user login, user akan di arahkan ke dalam tampilan halaman awal user. Disinilah user bisa melakukan pengajuan proposal penelitian dosen.

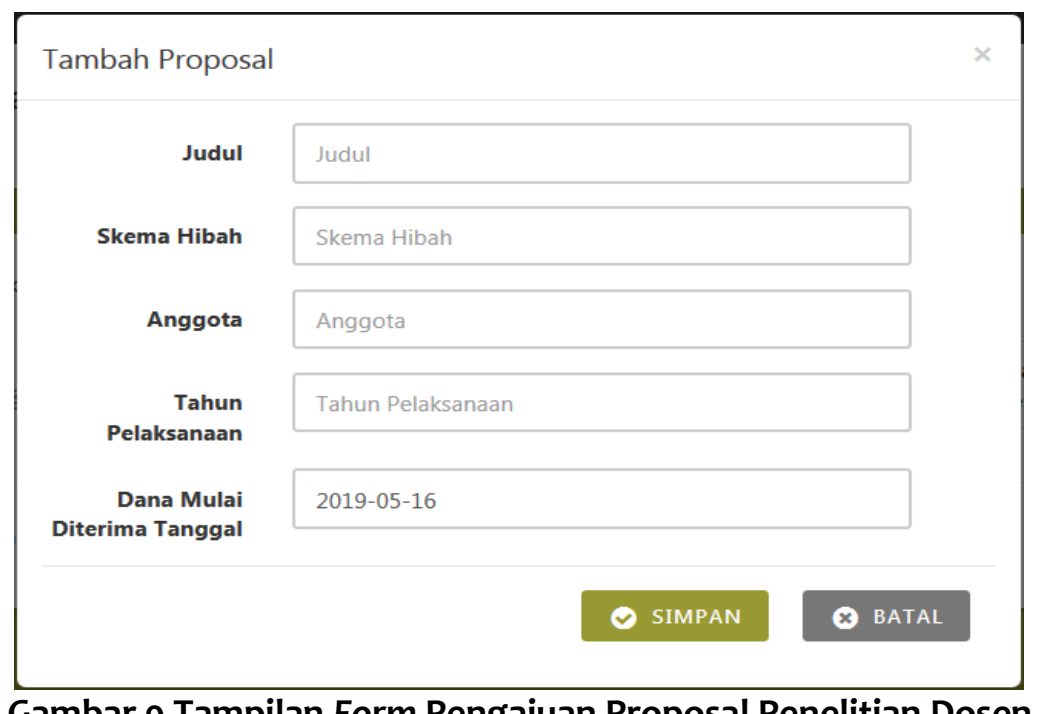

Gambar 9 Tampilan Form Pengajuan Proposal Penelitian Dosen

Gambar 9 di atas merupakan tampilan form pengajuan proposal penelitian dosen, Disini user harus memasukkan Judul, Skema Hibah, Anggota, Tahun Pelaksanaan, dan Dana Mulai Diterima Tanggal. Setelah itu user cukup meng-klik tombol Simpan dan data pengajuan proposal penelitian dosen akan disimpan ke dalam database.

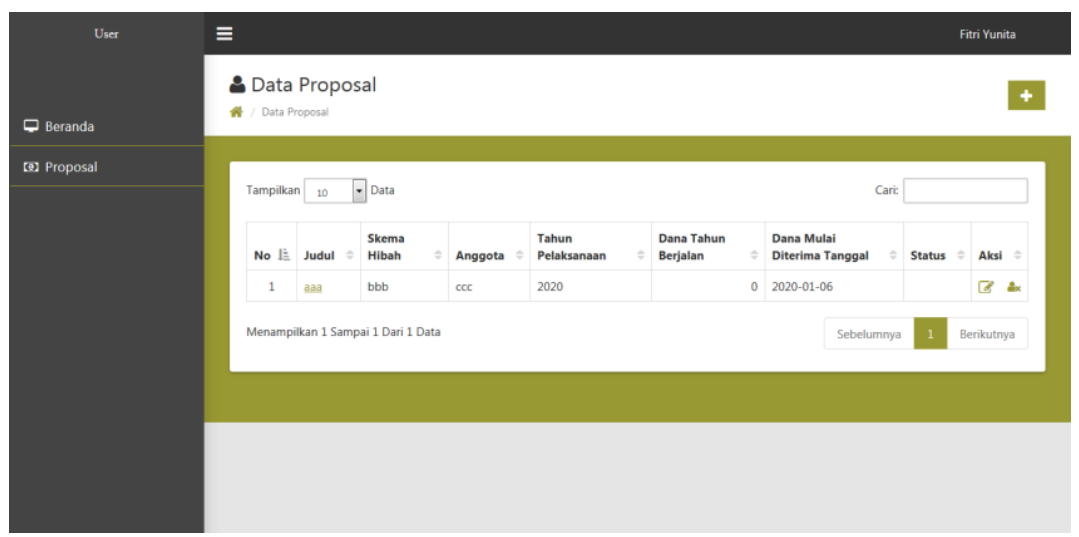

Gambar 10 Tampilan Halaman Data Proposal

Gambar 10 di atas merupakan tampilan halaman data proposal yang telah diinputkan oleh user. Disini admin dapat mengubah keterangan pengajuan menjadi Diterima atau Ditolak. Dan juga admin dapat mencetak laporan persetujuan yg telah selesai disetujui. 


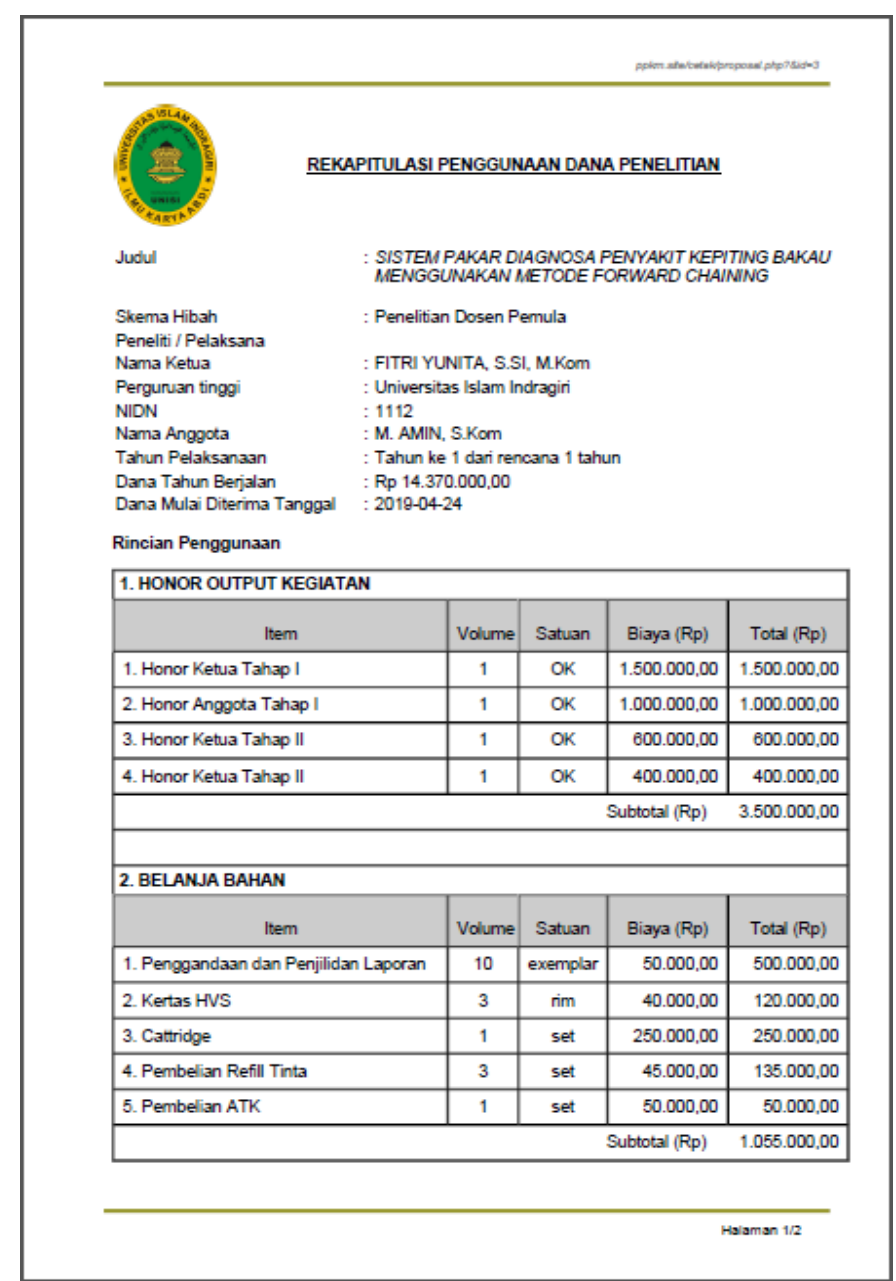

Gambar 11 Output Laporan Proposal Penelitian Dosen

Gambar 11 di atas merupakan tampilan dari laporan proposal penelitian dosen yang telah diterima oleh admin. Laporan proposal penelitian dosen ini dapat dicetak oleh user maupun admin.

\section{KESIMPULAN}

Beberapa hal yang dapat disimpulkan dari penelitian ini adalah sebagai berikut:

1. Dengan adanya sistem informasi penyusunan anggaran proposal penelitian dosen ini, dapat membantu seorang dosen dalam melakukan identifikasi kesalahan penyusunan anggaran pada proposal dosen.

2. Dengan adanya sistem informasi penyusunan anggaran proposal penelitian dosen ini, dapat memberikan informasi secara mudah dan cepat tentang kesalahan tidak validnya pengkalkulasian dalam penyusunan anggaran proposal dosen.

3. Dengan adanya sistem informasi penyusunan anggaran proposal penelitian dosen ini, dapat membangun sistem informasi penyusunan anggaran proposal dosen menggunakan software PHP sehingga tidak membutuhkan banyak waktu dan biaya bagi penggunanya.

\section{REFERENSI}

[1] Hamim Tohari, (2013), Analisis serta Perancangan Sistem Informasi melalui Pendekatan UML, Andi, Yogyakarta.

[2] Winarno Wing Wahyu, (2006), Sistem Informasi Akuntansi, UPP STIM YKPN, Yogyakarta.

[3] Andri Kristanto, (2007), Perancangan Sistem Informasi dan Aplikasinya, Gava Media, Yogyakarta. 
[4] A. Kadir. (2014), pengenalan Sistem Informasi Edisi Revisi. Andi, Yogyakarta.

[5] Al-Bahra Bin Ladjamuddin. B, (2005), Analisis dan Desain Sistem Informasi, Graha Ilmu, Yogyakarta.

[6] D. A. A. a K. Falgenti. (2017), Jurnal Teknologi dan Sistem Informasi Sistem Informasi Penjualan Berbasis Kinerja pada Proyek Apartemen Mega City Bekasi, vol. 03, pp. 343-352.

[7] Ralph M. Stair, \& George W. Reynolds. (2010), Information System (Ninth Edition), Course Technology Cengage Learning

[8] Nugroho. A. (2014). Rekayasa Perangakat Lunak Berorientasi Objek Dengan Metode USDP, Andi, Yogyakarta.

[9] Priana, I., \& Fitriani, L. (2016), Perancangan Aplikasi Perangkat Lunak Pengelolaan Data Bank Sampah Di PT. Inpower Karya Mandiri Garut, Jurnal Algoritma Sekolah Tinggi Teknologi Garut, Vol. 14 No. 1.

[10] Said Hasibuan, M. (2010), Design dan Implementasi E-Jurnal sebagai Peningkatan Layanan Jurnal Di Kopertis Wilayah 2, Seminar Nasional Aplikasi Teknologi Informasi, 46-50.

[11] Adiyanto, Suraya, \& Sutanta, E. (2013), Integrasi Aplikasi Web dan SMS Gateway pada TPI Gempolsari menggunakan Php dan Mysql, Jurnal JARKOM, 49-56.

[12] Watung, I. A., Alicia, Sinsuw, Sari, \& Paturusi. (2014), Perancangan Sistem Informasi Data Alumni Fakultas Teknik UNSRAT Berbasis Web, E-journal Teknik Elektro dan Komputer, 1-9.

[13] Aspriyono, H., \& Jauhari (2012), Sistem Pelayanan Online pada SD Negeri 62 Kota Bengkulu Menggunakan Adobe Dreamweaver CS4, ISSN 1858 - 2680.

[14] M. S. Mustaqbal, R. F. Firdaus, and H. Rahmadi. (2015), Pengujian Aplikasi menggunakan Black Box Testing Boundary Value Analysis (Studi Kasus : Aplikasi Prediksi Kelulusan SNMPTN), Jurnal IImiah Teknologi Informasi Terapan, Volume I, No 3

[15] Nidhra, S., and Dondeti, J. (2012), BLACK BOX AND WHITE BOX TESTING TECHNIQUES -A LITERATURE REVIEW, International Journal of Embedded Systems and Applications (IJESA), Vol. 2, No. 2. 